\title{
Engineering for Success: Approaches to Improve Chimeric Antigen Receptor T Cell Therapy for Solid Tumors
}

\author{
Melinda Mata ${ }^{1} \cdot$ Stephen Gottschalk ${ }^{2}$
}

Published online: 23 February 2019

๑) Springer Nature Switzerland AG 2019

\begin{abstract}
While impressive clinical responses have been observed using chimeric antigen receptor (CAR) T cells targeting CD19+ hematologic malignancies, limited clinical benefit has been observed using CAR T cells for a variety of solid tumors. Results of clinical studies have highlighted several obstacles which CAR T cells face in the context of solid tumors, including insufficient homing to tumor sites, lack of expansion and persistence, encountering a highly immunosuppressive tumor microenvironment, and heterogeneous antigen expression. In this review, we review clinical outcomes and discuss strategies to improve the antitumor activity of CAR T cells for solid tumors.
\end{abstract}

\section{Key Points}

Early phase clinical testing of chimeric antigen receptor (CAR) T cells for solid tumors has demonstrated safety, but limited antitumor activity.

Key roadblocks for limited CAR T cell efficacy for solid tumors have been identified including heterogenous antigen expression, homing to tumor sites, and the immunesuppressive tumor microenvironment.

Genetic engineering approaches to overcome 'roadblocks' of CAR T cell therapy for solid tumors have been devised and successfully tested in preclinical models.

'Improved' CAR T cells are set to be evaluated in early phase clinical studies within the next 5 years.
Stephen Gottschalk

stephen.gottschalk@stjude.org

Immatics US, Inc, Houston, TX 77030, USA

2 Department of Bone Marrow Transplantation and Cellular Therapy, St Jude Children's Research Hospital, 262 Danny Thomas Place, MS321, Memphis, TN 38105, USA

\section{Introduction}

In the field of cancer immunotherapy, adoptive immunotherapy with $\mathrm{T}$ cells, genetically engineered to express chimeric antigen receptors (CARs), is a fast-growing approach to treat aggressive and recurring malignancies. CARs are engineered fusion proteins that couple the antigen recognition capability of an antibody with the effector function of an immune cell, thereby directing cell specificity towards a tumor cell [1-4]. Unlike the T cell's conventional antigen recognition mechanism, CARs recognize antigens on the target cell surface in their unprocessed form and in a major histocompatibility complex (MHC)-independent manner (Fig. 1). In this way, CAR T cells are able to recognize antigenic epitopes that would normally not have been seen by $\mathrm{T}$ cells, and also circumvent immune evasion strategies by which tumors avoid MHC-restricted T cell recognition, such as decreased expression of MHC molecules and/or defects in antigen processing.

Remarkable clinical responses using CAR T cells for the treatment of CD19+ hematological malignancies have been observed [5-11], leading to US Food and Drug Administration (FDA) approval of two CD19-CAR T cell products in 2017. In addition, remarkable, durable responses have been observed with the adoptive transfer of CAR T cells targeting $\mathrm{B}$ cell maturation antigen-positive (BCMA+) multiple myeloma [12]. However, clinical observations thus far for solid tumors and brain tumors have been disappointing, with only a handful of patients showing responses (Table 1). The significant variability in targeted antigen expression, 


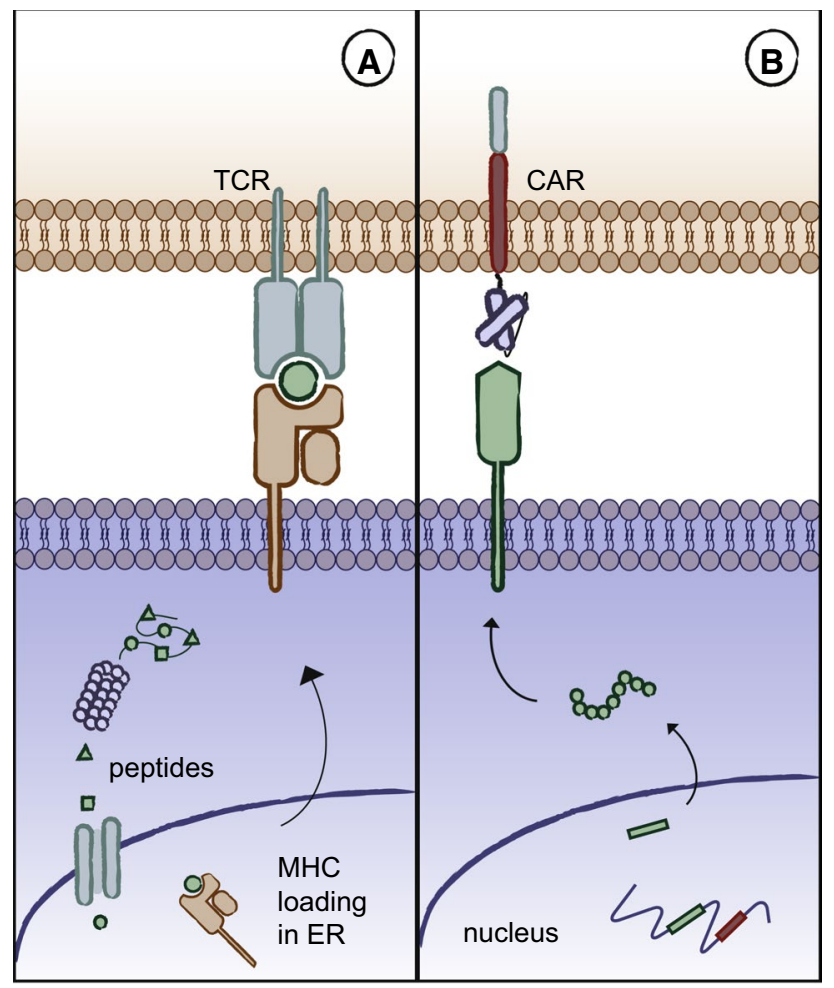

Fig. 1 Antigen recognition mechanism of chimeric antigen receptors (CARs). a Antigens are processed within tumor cells and the major histocompatibility complex (MHC) presents antigenic peptides on the surface of tumor cells. $T$ cells recognize antigens by an interaction with the $\mathrm{T}$ cell receptor (TCR) and peptide/MHC complex. b CAR $\mathrm{T}$ cells recognize cell-surface antigens on tumor cells in an unprocessed manner independent of MHC. ER endoplasmic reticulum
CAR design, and heterogeneity of enrolled patients make it exceedingly difficult to compare outcomes. However, these clinical studies have highlighted key deficiencies of current CAR T cells and have provided the impetus for improvement and redesign in the research setting. In this review we summarize how the observed clinical results have shaped current approaches that are actively being investigated to overcome the hurdles for CAR T cell therapy for solid tumors.

\section{Evolution of Chimeric Antigen Receptor (CAR) Design}

CARs, originally termed $\mathrm{T}$ bodies and first developed by Zelig Eshhar [13, 14], have now progressed to a more sophisticated single molecule that encompasses several facets of $\mathrm{T}$ cell activation and effector function. In its simplest form, a CAR molecule consists of an extracellular antigen recognition domain, a hinge, a transmembrane domain, and an intracellular signaling domain. The extracellular antigen recognition domain most commonly consists of a single chain variable fragment ( $\mathrm{scFv}$ ) derived from a monoclonal antibody $(\mathrm{mAb})$ targeting a particular antigen but can also comprise ligands or peptides that bind to molecules expressed on the cell surface of tumors $[15,16]$. Different hinges, long or small, have been evaluated, and studies indicate that the hinge is not only a structural component of the CAR but greatly influences its function [17]. Commonly used transmembrane domains include the transmembrane domain of CD28 or CD8 $\zeta$. Original CARs, called

Table 1 Selected, published clinical studies with chimeric antigen receptor T cells for solid tumors

\begin{tabular}{|c|c|c|c|c|c|c|}
\hline Target antigen & Diseases & $\mathrm{T}$ cell product & Signaling domain & $\begin{array}{l}\text { Chemotherapy } \\
\text { prior to T cells }\end{array}$ & Comment & References \\
\hline$\alpha \mathrm{FR}$ & Ovarian cancer & ATC; retrovirus & $\zeta$ & No & No response & [18] \\
\hline CAIX & Renal cancer & ATC; retrovirus & $\zeta$ & No & No response; cholangitis & {$[123,124]$} \\
\hline CD133 & $\begin{array}{l}\text { HCC, CRC, Pan- } \\
\text { creatic cancer }\end{array}$ & ATC; lentivirus & 4-1BB. $\zeta$ & $\mathrm{Yes}^{\mathrm{a}}$ & $3 / 23 \mathrm{PR}, 14 / 23 \mathrm{SD}$ & [149] \\
\hline CD171 & NB & $\mathrm{T}$ cell clone; plasmid & $\zeta$ & No & $1 / 6 \mathrm{PR}$ & [19] \\
\hline CEA & $\mathrm{CRC}$ & ATC; lentivirus & 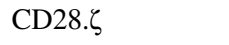 & Yes & $7 / 10 \mathrm{SD}$ & {$[150]$} \\
\hline CEACAM5 & CRC & ATC; retrovirus & $\zeta$ & Yes & 7/14 SD & [151] \\
\hline GD2 & NB & $\begin{array}{l}\text { ATC/VST; retroviral } \\
\text { transduction }\end{array}$ & $\zeta$ & No & 3/11 CR & {$[44,45]$} \\
\hline GD2 & NB & ATC; retrovirus & CD28.OX40.ร & Yes & $5 / 11 \mathrm{SD}$ & [28] \\
\hline HER2 & Colon cancer & ATC; retrovirus & CD28.4-1BB. $\zeta$ & Yes & 1/1 ARDS & {$[125]$} \\
\hline HER2 & Sarcoma & ATC; retrovirus & 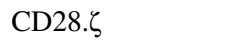 & No & 4/17 SD & {$[126]$} \\
\hline Mesothelin & Pancreatic cancer & ATC; mRNA & $4-1 \mathrm{BB} \cdot \zeta$ & No & $2 / 6 \mathrm{SD}$ & [25] \\
\hline
\end{tabular}

$\alpha F R \alpha$-folate receptor, ARDS acute respiratory distress syndrome, $A T C$ polyclonal, activated T cells, $C A I X$ carboxy-anhydrase-IX, $C E A$ carcinoembryonic antigen, $C E A C A M 5$ carcinoembryonic antigen-related cell adhesion molecule 5, $C R$ complete response, $C R C$ colorectal cancer, $H C C$ hepatocellular carcinoma, HER2 human epidermal growth factor receptor 2, $m R N A$ messenger RNA electroporation, $N B$ neuroblastoma; plasmid plasmid transfection, $P R$ partial response, $S D$ stable disease, VST virus-specific T cells

${ }^{\mathrm{a}}$ Only for non-HCC patients 
first-generation CARs, only contained the CD3 $\zeta$ chain or the $\mathrm{Fc}$ receptor $\gamma$ chain as an endodomain to activate $\mathrm{T}$ cell signaling upon antigen encounter.

Results from 'first-in-human' clinical studies with firstgeneration CAR $\mathrm{T}$ cells for solid tumors showed safety but had rather disappointing antitumor responses and low persistence of infused T cells. Kershaw et al. [18] infused autologous CAR T cells targeting $\alpha$-folate receptor $(\alpha$ FRCAR) into patients with ovarian cancer. All 14 patients had progressive disease and $\alpha$ FR-CAR T cells only persisted $2-3$ weeks, with a peak at 5 days [18]. In a separate study, firstgeneration CAR T cells targeting CD171 were infused into neuroblastoma patients, with one of six patients having a partial response that was seen at day 56 post $T$ cell infusion but was not maintained [19]. Similarly, in vivo CAR T cell persistence was low and mainly seen within the first week post-infusion, with only one patient having detectable CAR $\mathrm{T}$ cells by polymerase chain reaction (PCR) at day 42 .

Limited $\mathrm{T}$ cell persistence in these first trials is most likely due to several factors, including insufficient $\mathrm{T}$ cell activation from first-generation CARs that lack appropriate co-stimulation. Different co-stimulatory molecules such as CD28, 4-1BB, OX40, CD27, ICOS, or DAP12 have been added to enhance CAR T cell activation [1-4, 20,21]. Depending on the number of added co-stimulatory domains, these CARs are referred to as second generation (one co-stimulatory endodomain) or third generation (two co-stimulatory endodomains).

The CD28 signaling domain, which is the canonical second signal for $\mathrm{T}$ cell activation, was therefore incorporated into CARs (Fig. 2) and subsequently has been shown to induce greater CAR T cell persistence in direct comparison to first-generation CARs in patients [22]. Several groups have also shown that activating 4-1BB signaling rather than CD28 signaling prevented exhaustion, improved T cell survival, and enhanced formation of central memory $\mathrm{T}$ cells $\left(\mathrm{T}_{\mathrm{CM}}\right)$ in preclinical studies [23, 24]. To this end, a direct comparison between CD28- and 4-1BB-containing constructs is currently underway in the clinic using a CD19specific CAR (ClinicalTrials.gov identifier NCT01853631). The use of 4-1BB co-stimulation in CAR T cells for solid tumors is still under investigation, and only limited data are available with mesothelin-specific CAR T cells for pancreatic cancer (Table 1), and with epidermal growth factor receptor (EGFR) variant III (EGFRvIII)- or interleukin (IL)-13 receptor subunit $\alpha 2$ (IL-13R $\alpha 2$ )-CAR T cells for high-grade glioma [25-27]. In addition, third-generation GD2-CAR T cells with a CD28.OX40. $\zeta$ endodomain have been evaluated in patients with neuroblastoma. While infusion of CAR T cells was safe, their antitumor activity was limited [28]. The activation of 4-1BB signaling by expressing 4-1BB ligand (4-1BBL) on the cell surface of T cells (co-stimulation in trans), as opposed to simultaneous signaling in typical CAR constructs, may also be a promising approach as it mimics physiological separation of $\mathrm{T}$ cell signaling and has also been shown to have potent antitumor properties [29, 30].

In summary, studies have highlighted that no universal CAR construct for all malignancies exists, but rather each CAR must be optimized for the targeted antigen and each
Fig. 2 Second-generation chimeric antigen receptor (CAR) design. While in conventional antigen recognition (signal 1) and co-stimulation (signal 2) are separated, second-generation CARs simultaneously transmit signals 1 and 2. APC antigenpresenting cell, $M H C$ major histocompatibility complex, $T C R$ T cell receptor

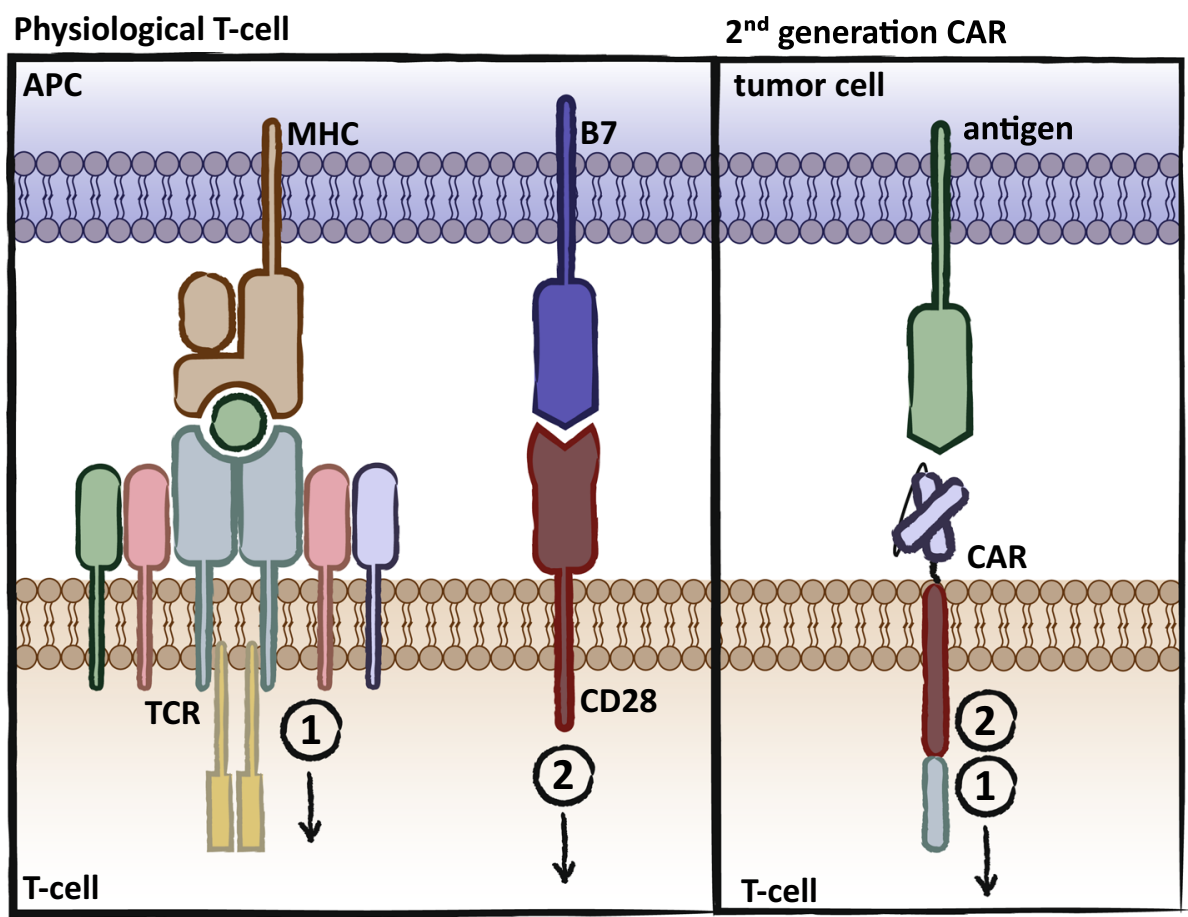


tumor setting. We are hopeful that current clinical studies with CAR T cells may shed more light on the best CAR construct and/or co-stimulatory domains in the context of various solid tumors. However, second- genetic modifications of CAR T cells or expressing CARs in less differentiated $T$ cell subsets will also be important. These approaches are summarized in Fig. 3, and are discussed in detail in Sects. $3,3.4,4,5$, and 7 .

\section{Promoting Expansion and Persistence of CAR T Cells After Infusion}

Robust antitumor activity is directly correlated with the expansion and persistence of infused cells, thereby making it a vital component of CAR T therapy [31-33]. In trials using
CAR T cells directed towards CD4 for the treatment of HIV, CAR T cells were able to persist up to 9 years after infusion and modeling of acquired data showed a disappearance halflife of $>16$ years [34]. In addition, CAR T cells targeting CD19+ chronic lymphocytic leukemia (CLL) were shown to persist up to 49 months, resulting in 4 of 14 complete responses and concurrent $\mathrm{B}$ cell aplasia [8]. These results demonstrate that it is possible for CAR T cells to expand and persist long-term in vivo. Adverse effects of CD19-CAR $\mathrm{T}$ cell therapies such as cytokine release syndrome (CRS) correlate with tumor burden [35], suggesting that the presence of target antigen on malignant cells is critical for CAR $\mathrm{T}$ cell activation and expansion. However, whether antigenic stimulation by normal CD19+ B cells contributes to the long-term persistence of CD19-CAR T cells is difficult to ascertain.
Fig. 3 Overcoming obstacles using chimeric antigen receptor (CAR) $\mathrm{T}$ cells for the treatment of solid tumors. Various approaches have been developed to enhance CAR T cell function in the context of solid tumors. Starting at the top of the figure and proceeding counter clockwise, these include (i) optimizing CAR design by using 4-1BB co-stimulation in cis or trans; (ii) expressing signal converters or dominant negative receptors; (iii) improving homing to tumors by expression of distinct chemokine receptors; (iv) promoting expansion and persistence of infused $\mathrm{T}$ cells using cytokines or cytokine receptors; (v) overcoming antigen heterogeneity or antigen loss by expression of CARs targeting two tumor antigens; (vi) selecting $\mathrm{T}$ cell subsets for genetic modification; and/ or (vii) enhancing their safety. $C C R$ C-C chemokine receptor, $I L$ interleukin, $T_{C M}$ central memory T cells, $T_{S C M}$ memory stem T cells, $t E G F R$ truncated epidermal growth factor receptor, $T G F \beta R$ transforming growth factor $\beta$ receptor, TLR4 Toll-like receptor 4

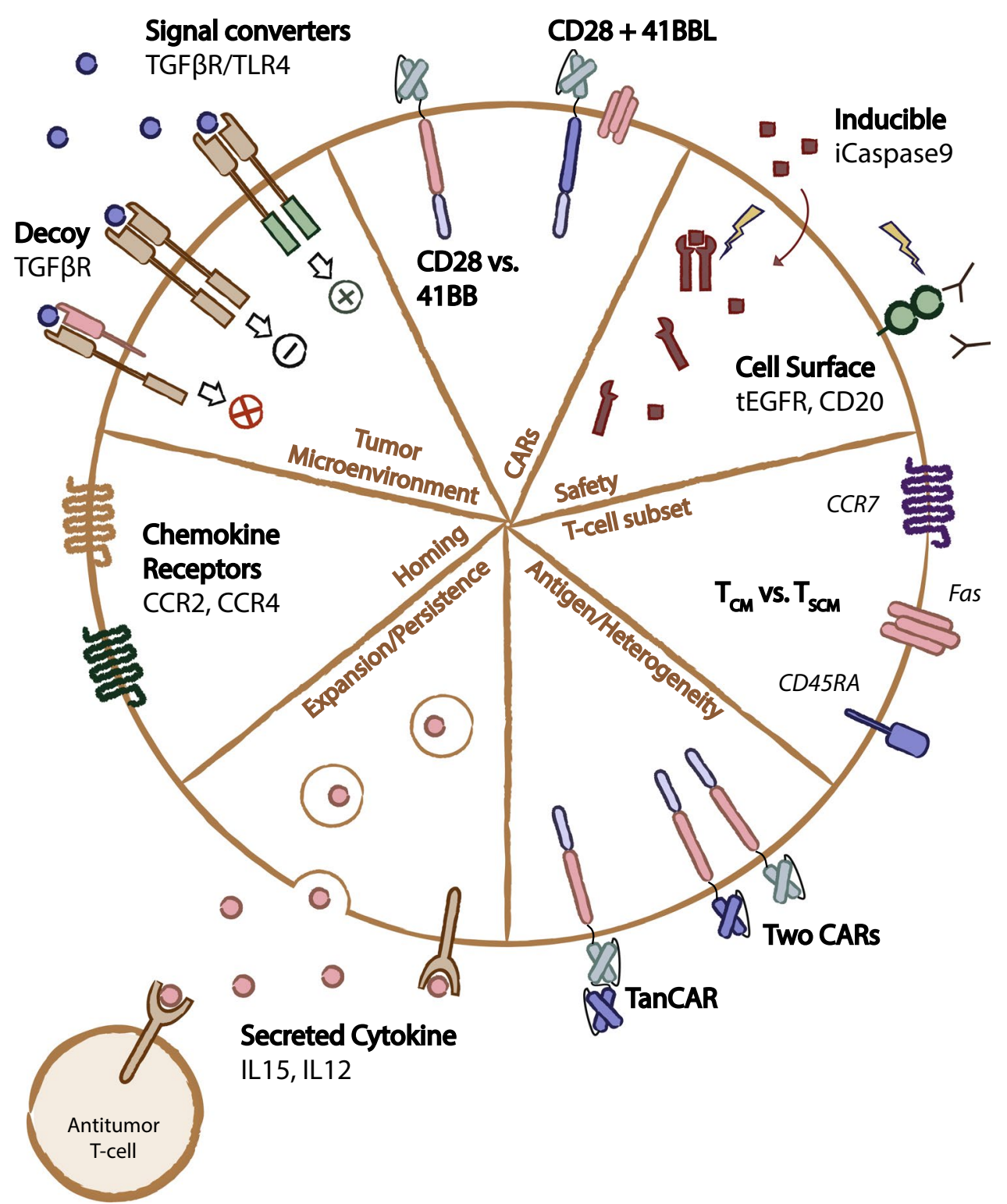


Studies using CAR T cells in the context of solid tumors have unfortunately shown minimal expansion and persistence (Table 1). To promote expansion and persistence after CAR T cell infusions in the solid tumor milieu, several approaches have been explored both preclinically and clinically.

\subsection{Grafting CARs on T Cell Subsets}

Since $\mathrm{T}$ cells transition through various stages of differentiation that are characterized by a progressive loss of function, the differentiation status of CAR T cells is an important consideration for optimizing their expansion, persistence, and antitumor activity. Several preclinical studies have corroborated that the antitumor potential progressively decreases as $\mathrm{T}$ cells further differentiate from naïve $\left(T_{\mathrm{N}}\right)$ to the newly characterized memory stem cells $\left(T_{\mathrm{SCM}}\right)$ to $\mathrm{T}_{\mathrm{CM}}$ to effector memory $\left(T_{\mathrm{EM}}\right)$ and then effector $\mathrm{T}$ cells $\left(T_{\mathrm{E}}\right)$ [36-38].

Most clinical trials thus far have relied on the infusion of genetically modified bulk $\mathrm{T}$ cells initially obtained from peripheral blood, potently activated with anti-CD3 and antiCD28 mAbs, and then expanded ex vivo with IL-2. While effective in generating large numbers of $T$ cells for adoptive therapy, these approaches often differentiate $\mathrm{T}$ cells further to the point of inferior persistence and heterogeneous function in vivo [39]. Preferentially selecting a defined CD8+ and CD4+ subset prior to infusion could lead to enhanced antitumor efficacy in the solid tumor setting as has been seen with CD19-CAR T cells for leukemia [11, 40, 41]. Indeed, one recent publication demonstrated that CAR CD4+ T cells have superior antitumor activity in preclinical high-grade glioma models, and that mixing these with CAR CD8+ $T$ cells impaired their effector function [42].

CARs have also been engrafted onto virus-specific $\mathrm{T}$ cells with the rationale that in vivo antigen stimulation and co-stimulation received after engagement of their native $\mathrm{T}$ cell receptor (TCR) will promote persistence of CAR $\mathrm{T}$ cells. However, there is an intricate interplay between the expressed CAR and native virus-specific TCR requiring detailed analysis [43]. These bi-specific $\mathrm{T}$ cells have accordingly shown increased expansion and persistence in neuroblastoma patients compared with $\mathrm{T}$ cells expressing the same CAR but lacking viral specificity [44]. A long-term followup of this study showed complete responses in three of 11 patients with bi-specific $\mathrm{T}$ cells persisting up to 96 weeks [45]. Clinical trials are currently underway for other solid tumors, including cytomegalovirus-specific human epidermal growth factor receptor 2 (HER2)-CAR T cells for glioblastoma (NCT01109095) and varicella zoster virus-specific GD2-CAR T cells for sarcoma (NCT01953900), and in part have been published [46].

Transducing specific $\mathrm{T}$ cell subsets with CARs has also improved their effector function. For example, investigators have shown that expressing CARs with an inducible $\mathrm{T}$ cell co-stimulator (ICOS) endodomain in $\mathrm{T}$ helper (Th) 17 cells mediates potent antitumor activity [20, 21]. More recently, the same group of investigators has also shown that mixing CD4+ T cells expressing CARs with an ICOS co-stimulatory endodomain and CD8+ T cells expressing CARs with a 4-1BB co-stimulatory endodomain results in superior antitumor activity [21]. Careful analysis of ongoing CD19-CAR T cell therapy studies have also provided insight into which $\mathrm{T}$ cell subset is most effective. For example, for CLL antitumor activity of $\mathrm{T}$ cells expressing a CD19-CAR with a 4-1BB. $\zeta$ endodomain correlated with the presence of $\mathrm{CD} 27+\mathrm{PD}-1$ (programmed death-1)-CD8+ CAR T cells expressing high levels of the IL-6 receptor in the T cell product [32]. The recent discovery that epigenetic programs are critical for $\mathrm{T}$ cell fate [47, 48], and that epigenetic reprograming can halt $\mathrm{T}$ cell exhaustion undoubtedly has the potential to further increase the potency of CAR T cells. This is probably best highlighted by a case report in which lentiviral integration into the methylcytosine dioxygenase TET2 gene locus significantly enhanced CAR $\mathrm{T}$ cell function [49].

In addition, various methods have been shown to 'halt' $\mathrm{T}$ cells in a less differentiated state to maximize therapeutic efficacy. The use of IL-7 and IL-15, as opposed to IL-2, during the ex vivo generation of CAR T cells can promote the frequency of CD8+CD45RA+CCR (C-C chemokine receptor) $7+$ stem cell-like $\mathrm{T}$ cells that induce superior antitumor functionality [50, 51]. The IL-7/IL-15 cytokine combination for ex vivo generation of CD19-CAR T cells is currently being compared to IL-2 in the clinical setting (NCT02652910). Furthermore, the use of another $\gamma_{c}$ cytokine, IL-21, has been shown to prevent differentiation of genetically modified $\mathrm{T}$ cells and enhance antitumor activity compared to cells expanded in IL-2 [52, 53].

Alternative approaches to prevent $\mathrm{T}$ cell differentiation include modulating metabolic or developmental pathways in $\mathrm{T}$ cells. For example, activation of the $\mathrm{Wnt} / \beta$-catenin signaling pathway, involved in various stages of $\mathrm{T}$ cell development, can also delay $\mathrm{T}$ cell differentiation towards a more naïve phenotype with greater antitumor capabilities than memory $\mathrm{T}$ cells $[54,55]$. Additional molecules that target metabolic pathways including the use the mammalian target of rapamycin (mTOR) inhibitor rapamycin [56] or AKT inhibitors [57] have been shown to promote the function of minimally differentiated memory cells. While these approaches have not yet been studied in the clinical setting for solid tumors, ex vivo expansion of CAR T cells that promote less differentiated cells may produce long-lasting antitumor effects after infusion. Lastly, a recent study indicates that successive cycles of chemotherapy significantly depletes $T_{\mathrm{N}}$ subsets, arguing that it might be advisable to 
obtain a leukopheresis product at diagnosis in high-risk solid tumor patients for future CAR T cell production [58].

\subsection{Lymphodepletion Prior to T Cell Infusion}

Lymphopenia has been shown to augment $\mathrm{T}$ cell expansion and increase $\mathrm{T}$ cell responsiveness, possibly due to the destruction of regulatory cells or the increased levels of homeostatic cytokines such as IL-7. To this end, several studies have shown that lymphodepletion prior to adoptive $\mathrm{T}$ cell therapy, including CAR T cells, has improved both expansion and function of infused $\mathrm{T}$ cells $[41,59]$. Lymphodepleting $\mathrm{mAbs}$ are one attractive strategy to replace chemotherapy. For example, infusion of a pair of rat CD45 $\mathrm{mAbs}$, which have a short half-life in humans, prior to $\mathrm{T}$ cell transfer induced transient lymphodepletion, resulting in enhanced, albeit limited, expansion of adoptively transferred $\mathrm{T}$ cells [60]. Additionally, infusion of the humanized CD52 $\mathrm{mAb}$ alemtuzumab induces profound lymphodepletion; however, it was deemed unsuitable to aid $\mathrm{T}$ cell expansion since the infused T cells also express CD52 [61]. Preclinical studies have shown that $\mathrm{T}$ cells in which CD52 expression is silenced readily expand post-CD52 mAb infusion, and encouraging results from one early phase clinical study for CD19+ malignancies have been reported [62].

\subsection{Cytokine Support}

The uses of common $\gamma$ chain or pro-inflammatory cytokines that promote CAR T cell survival and augment the T cell antitumor immune response have been extensively explored. Exogenous cytokine administration of IL-2, IL-15, or IL-12 can be used to promote adoptive $\mathrm{T}$ cell expansion; however, there is concern regarding severe systemic toxicity [63-66]. To ensure local production of cytokines within the tumor environment, transgenic expression of IL-15 has been shown to promote survival and expansion of gene-modified cells in preclinical models [67-70]. Additionally, inducible IL-12 secretion after antigen encounter by CAR T cells has shown similar results in various preclinical murine models [71, 72]. However, 'first-in-human' studies of inducible IL-12 in tumor-infiltrating lymphocytes (TILs) still resulted in toxicities and prevented a dose escalation above $3 \times 10^{9}$ cells where transient clinical responses were seen in $63 \%$ of patients [73]. Recently, IL-12-secreting mucin (MUC)16specific CAR T cells showed more than five-fold lower expression of IL-12 compared with previously published reports, possibly due to either its construction in a tricistronic vector or location of the $I L 12$ gene behind an internal ribosome entry site (IRES) [74]. A phase I clinical study to evaluate safety of these CAR T cells for solid tumors is currently underway (NCT02498912). Lastly, transgenic expression of IL-18 is actively being explored to enhance the effector function of CAR T cells in preclinical models [75-77].

Cytokines that have minimal systemic toxicity, such as IL-7, have also been investigated. Expression of IL-7R $\alpha$ in combination with IL-7 administration has been shown to enhance $T$ cell expansion [78, 79]. In such an approach, T cells that were once unresponsive to IL-7 due to lack of the cytokine receptor are now able to receive survival and proliferation signals induced by IL-7. As an alternate strategy, investigators have expressed a constitutive active IL-7 receptor [80]. Other T cell homeostatic cytokines such as IL-21 have been tested in a preclinical setting and were shown to enhance CAR T cell efficacy [81].

\subsection{Improving Homing of CAR T Cells to Tumor Sites}

As infused $\mathrm{T}$ cells typically accumulate in the lung and shortly thereafter are also found in the liver and spleen, enhancing $\mathrm{T}$ cell homing to the tumor site is paramount to improve their antitumor activity and preventing potential adverse effects $[18,82]$. Efficient $\mathrm{T}$ cell homing is a multistep process that involves adhesion molecules and chemokine gradients. Tumors, and cells within the surrounding microenvironment, can secrete low levels of chemokines to prevent the accumulation of tumor-specific $\mathrm{T}$ cells or secrete chemokines that preferentially attract pro-tumor Th2 cells, myeloid-derived suppressor cells, or regulatory $\mathrm{T}$ cells (Tregs) [83]. To overcome these obstacles, transgenic expression of CCR 2 and CCR 4 on CAR $\mathrm{T}$ cells resulted in enhanced trafficking of CAR T cells to tumor sites leading to increased tumor clearance in preclinical xenograft murine models [84-86]. Alternatively, a small peptide expressed on CAR T cells that blocks the negative effects of protein kinase A on TCR activation was shown to also upregulate $\mathrm{C}-\mathrm{X}-\mathrm{C}$ chemokine receptor (CXCR) 3 and the CD49d integrin expression on CAR T cells, leading to enhanced migratory and tumor infiltration properties [87]. Although these approaches have not been tested in the clinic with CAR T cells, an ongoing clinical study is currently in progress with autologous TILs genetically modified to express CXCR2 to evaluate trafficking of T cells in metastatic melanoma patients (NCT01740557).

Other approaches to enhance $\mathrm{T}$ cell homing to tumor sites include the use of oncolytic viruses that preferentially replicate in tumor cells and are genetically modified to secrete chemokines. For example, an oncolytic adenovirus armed to secrete IL-15 and the chemokine RANTES (regulated upon activation normal $\mathrm{T}$ cell expressed and secreted) showed improved GD2-CAR T cell infiltration into tumors resulting in increased persistence and antitumor function in preclinical models [88]. In addition, simply injecting $\mathrm{T}$ cells into or in proximity to tumor sites avoids the need for $\mathrm{T}$ cells to home to tumor sites [89]. Recently, intracranial injections 
of IL-13R $\alpha 2$-CAR T cells showed remarkable efficacy in one glioblastoma multiforme (GBM) patient with regression of intracranial and spinal metastases that lasted up to 7.5 months [26]. Separate phase I clinical studies to evaluate the intratumoral injection of HER2-CAR T cells in GBM patients (NCT02442297) and CAR T cells that recognize the epidermal growth factor receptor family in head and neck cancer patients (NCT01818323) are in progress. Lastly, regional delivery of mesothelin-CAR or fibroblast activation protein (FAP)-CAR T cells for treating pleural-based mesothelioma is also actively being explored (NCT02414269, NCT01722149).

\section{Overcoming Heterogeneity and Antigen Loss Variants}

Solid tumors show considerable variability in antigen expression to avoid immune recognition. Furthermore, despite the high complete response rates seen with CAR $\mathrm{T}$ cells for CD19+ leukemia, antigen loss variants (ALVs) have been described [90, 91]. Several strategies are being developed to target multiple antigens. These include designing CARs with two antigen recognition domains, expressing multiple CARs in one $\mathrm{T}$ cell, or infusion $\mathrm{T}$ cell products, which each express CARs with distinct specificity. These approaches have been explored in preclinical models for hematological malignancies [91-94] and clinical testing for hematological malignancies targeting CD19 and CD22 or CD19 and CD20 is in progress (NCT03448393, NCT03241940, NCT03019055). For solid tumors, preclinical studies have shown that targeting HER 2 and IL-13R $\alpha 2$ with bispecific CAR T cells prevents the development of ALVs [95]. In addition, the expression of three CARs within a single $\mathrm{T}$ cell has been reported to overcome immune escape [96]. Another approach to prevent ALVs is to combine the infusion of CAR T cells with the injection of an oncolytic virus encoding a bispecific antibody, which recognizes an antigen that is distinct from the CAR target [97].

\section{Counteracting the Immunosuppressive Tumor Microenvironment}

Unlike hematological malignancies, solid tumors flourish in restrictive locations and create a harsh immunosuppressive microenvironment that prevents the function of CAR $\mathrm{T}$ cells and tumor-specific T cells in general. For example, tumor cells express ligands for immune checkpoints such as PD-1, Lag-3 (lymphocyte activation gene-3), Tim-3 (T cell immunoglobulin and mucin-domain containing-3), and TIGIT (T cell immunoreceptor with immunoglobulin and immunoreceptor tyrosine-based inhibitory motif domains), and produce enzymes such as indoleamine-2,3-dioxygenase (IDO) or arginase, which deplete the essential amino acids tryptophan and arginine, respectively [98, 99]. Other immunosuppressive molecules include adenosine, cytokines such as IL-4 and IL-10, and tumor growth factor (TGF)- $\beta$ [100-103]. Thus, once T cells have successfully homed to the tumor sites, they still have significant obstacles to overcome. These also include physical barriers, such as the surrounding tumor stroma, that prevent CAR $\mathrm{T}$ cells from encountering malignant cells. Ex vivo expanded $\mathrm{T}$ cells lack expression of the enzyme heparanase that is essential for the degradation of the extracellular matrix (ECM) surrounding solid tumors. Engineering CAR T cells to express heparanase is one strategy to overcome this limitation and resulted in improved antitumor activity for solid tumors in preclinical models [104]. Additionally, targeting components of the tumor stroma itself, such cancer-associated fibroblasts (CAFs), is a potential strategy not only to decrease collagen content of the ECM but also counteract the immunosuppressive tumor environment since CAFs secrete immunosuppressive factors, such as TGF- $\beta$ [105-107].

Malignant and stromal cells can also attract immunosuppressive cells, such as myeloid-derived suppressor cells (MDSCs), Tregs, or tumor-associated macrophages (TAMs), which can express cell surface molecules or secrete inhibitory cytokines that further dampen the function of antitumor T cells [108]. For example, tumor cells may express PD ligand 1 (PD-L1), which can inhibit the effector function of T cells. A combination strategy with PD-1-blocking antibodies and CAR T cells can therefore potentially augment antitumor effects against solid tumors [109, 110]. Additionally, several genetic modification strategies have been developed to render $\mathrm{T}$ cells resistant to this hostile environment, including transgenic expression of dominant negative receptors or signal converters, which convert $\mathrm{T}$ cell inhibitory signals into stimulatory signals. TGF- $\beta$ is a widely used immune evasion strategy by tumors since it promotes tumor growth while drastically inhibiting tumor-specific cellular immunity [111]. The unfavorable effects of TGF- $\beta$ can be counteracted by modifying $\mathrm{T}$ cells to express a dominant-negative TGF- $\beta$ type II receptor (DNRII) [112, 113]. While this approach has not been evaluated for CAR T cells in a clinical study, this approach has been evaluated with cytotoxic $\mathrm{T}$ lymphocytes (CTLs) targeting Epstein-Barr virus (EBV)-positive lymphoma. Results of this clinical study suggest that DNRIImodified CTLs have improved antitumor activity comparison with unmodified CTLs [114]. While dominant-negative receptors only protect $\mathrm{T}$ cells from the immunosuppressive environment, 'signal converters' provide direct positive signals. For example, linking the extracellular domain of the TGF- $\beta$ type II receptor (RII) to the endodomain of Toll-like receptor 4 (TLR4) results in a chimeric receptor that not only renders $\mathrm{T}$ cells resistant to TGF- $\beta$, but also induces $\mathrm{T}$ cell 
activation and expansion [115]. A similar approach has also been used to convert inhibitory functions of IL-4 into T cell stimulatory signals $[116,117]$ and is currently undergoing phase I testing for head and neck cancer (NCT01818323).

\section{Targeting T Cell Metabolism to Improve CAR T Cell Function}

In addition to the discussed immune checkpoints that inhibit $\mathrm{T}$ cell function within the tumor microenvironment, competition for key nutrients including sugars, amino acids, and fatty acids and the hypoxic tumor microenvironment have also emerged as critical factors that restrict the antitumor activity of $\mathrm{T}$ cells $[118,119]$. The interested reader is referred to recent review articles that discuss in detail immune-metabolism cells and how they can be manipulated for therapeutic intent [118-120]. Quiescent T cells rely on oxidative metabolism and generated adenosine triphosphate through oxidative phosphorylation (OXPHOS). Once activated, $\mathrm{T}$ cells rely on increased glycolysis resulting in lactate production. For CAR T cells, one study has highlighted that CARs with a CD28 co-stimulatory endodomain preferentially induce glycolytic metabolism, whereas CARs with a 4-1BB co-stimulatory endodomain induce mitochondrial biogenesis and OXPHOS [24]. Thus, the choice of the CAR endodomain significantly influences $T$ cell metabolism post-stimulation. In addition, amino acids such as arginine and glutamine, which are often depleted within the tumor microenvironment, are critical for $\mathrm{T}$ cell proliferation [121]. Several strategies are currently being explored in preclinical models to improve the 'metabolic fitness' of adoptively transferred T cells. For example, the ex vivo loading of tumor-specific $\mathrm{T}$ cells with arginine resulted in improved antitumor activity. Other approaches include the use of metformin, which reduces hypoxia levels in tumors [122].

\section{Preventing Toxicity of CAR T Cells}

Most antigens targeted thus far with CAR T cells are not exclusively expressed on tumors, and low levels of expression in normal tissue has resulted in unforeseen 'on target/off cancer toxicity' in the clinical setting. For example, first-generation carboxy-anhydrase-IX (CAIX)-CAR T cells recognized CAIX expression on non-malignant bile duct epithelial cells, resulting in liver toxicities [123]. This 'on target/off cancer' toxicity could be prevented by infusing a CAIX-specific $\mathrm{mAb}$ prior to the infusion of CAIX-CAR T cells [124]. One patient died after receiving $1 \times 10^{10}$ third-generation trastuzumab-based HER2-CAR T cells and IL-2 after lymphodepleting chemotherapy for the treatment of metastatic colon cancer. This severe adverse event was attributed to low-level HER2 expression on normal lung epithelia [125]. However, in a separate clinical study with second-generation FRP5-based HER2-CAR T cells, no dose-limiting toxicity was observed in 17 sarcoma patients that had received no lymphodepleting chemotherapy and up to $1 \times 10^{8} / \mathrm{m}^{2} \mathrm{~T}$ cells [126]. Thus, conditioning regimen, T cell dose, and/or CAR design may affect the incidence and severity of 'on target/ off cancer toxicity'. In this section we review (i) controlling CAR expression and affinity; (ii) engineering of $\mathrm{T}$ cells to limit their activation to tumor sites; and (iii) suicide genes as measures to prevent toxicities of CAR T cells.

\subsection{Controlling CAR Expression and Affinity}

While stable expression of CAR constructs on T cells is needed to have sustained antitumor responses, CAR expression from messenger RNA (mRNA) electroporation offers a unique opportunity to prevent and/or screen for off-target effects in solid tumors since gene expression is transient. For example, mRNA electroporated CAR T cells can serve as a first pass to test for toxic effects towards normal tissue that may also express the targeted antigen but at lower levels [25, 127, 128]. One patient who received multiple doses of mRNA-electroporated CAR T cells developed an IgE-mediated anaphylactic shock most likely triggered by the extracellular domain of the CAR that was derived from a murine $\mathrm{mAb}$, highlighting another potential adverse effect of CAR T cell therapy [128].

Proof-of-concept studies have shown that $\mathrm{T}$ cells can be genetically engineered so that $\mathrm{T}$ cell recognition of one antigen expressed on tumor cells can induce expression of a CAR directed towards a second antigen (Fig. 4), thereby relying on an 'antigen address' to initiate full CAR $\mathrm{T}$ cell activity towards tumors [129]. These include synthetic notch (synNotch) receptors, which consist of an antigen binding domain, a transmembrane domain, and a transcriptional activator. Once the receptor binds the target antigen, the transcriptional activator is cleaved and can then induce expression of a gene such as a $C A R$, which is under the control of the cleaved transcriptional activator [129]. As an additional method, modifying the affinity of antigen binding of the CAR could also potentially prevent the recognition of tumor antigen expressed at a low level on normal tissue, yet retain CAR activity against overexpressed antigens on tumor cells $[130,131]$.

\subsection{Engineering of T Cells to Limit their Activation to Tumor Sites}

While tumor antigen discovery is actively being pursued, it might be impossible to discover single surface antigens that are uniquely expressed in solid tumors but not expressed on the cell surface of normal tissues. Tumors most likely 


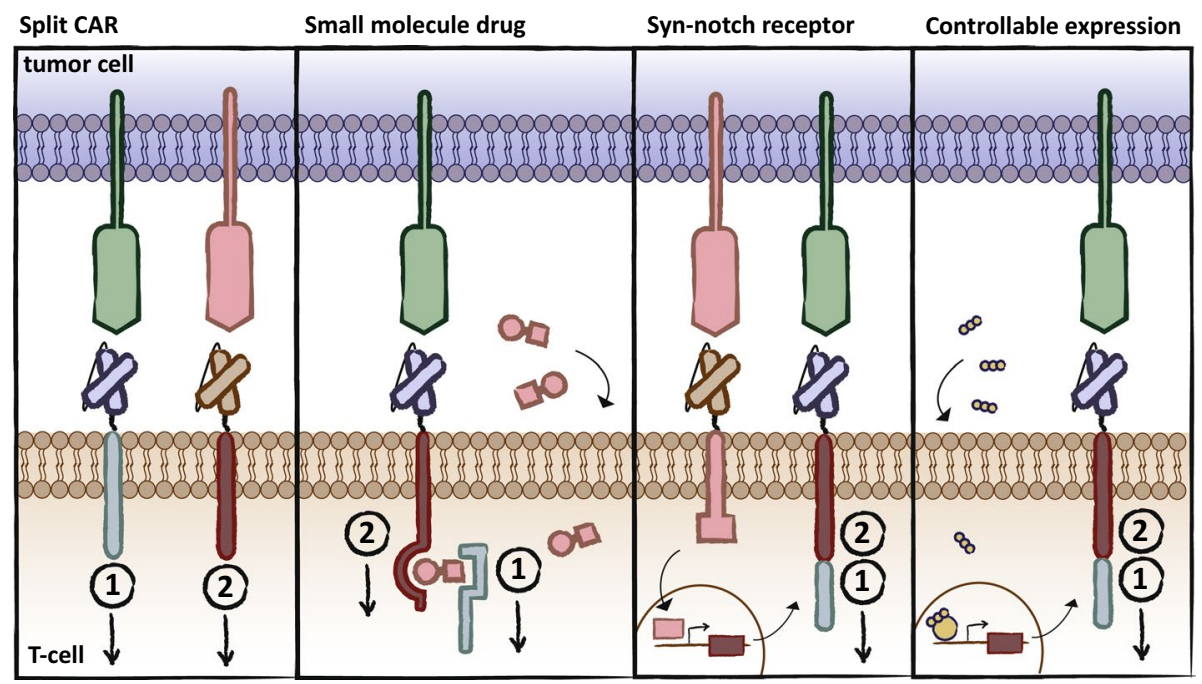

Fig. 4 Designing chimeric antigen receptors (CARs) to prevent toxicities. Several strategies have been developed to tune CAR activity. Four examples are illustrated (from left to right): (i) signals 1 and 2 can be split on two CARs with different antigen recognition domains, limiting full CAR T cell activation to sites, which express both anti-

express a unique pattern of antigens, which can be exploited using genetically modified $\mathrm{T}$ cells. For example, T cells have been engineered to express two CARs with different antigen specificity. One CAR provides antigen-specific $\zeta$-activation, while the second CAR provides antigen-specific co-stimulation, thereby restricting full $\mathrm{T}$ cell activation to tumors, which express a 'unique tumor antigen address' (Fig. 4) [132-134]. For this approach to work, the two targeted antigens must not be present together in a single location within normal tissues; thus, antigen selection will be critical for this approach to work. Differential antigen expression can also be used to inhibit $\mathrm{T}$ cell signaling. In this strategy, T cells are engineered to expresses two CARs: (1) a typical CAR construct that can activate $\mathrm{T}$ cell signaling once a tumorassociated antigen has been recognized; and (2) a CAR construct with a scFv targeting an antigen that is expressed on normal tissue that contains endodomains with inhibitory signaling such as PD-1 or cytotoxic T lymphocyte-associated antigen 4 (CTLA-4) [135]. CAR T cells expressing these receptors have limited function at off-target sites but can still effectively maintain antitumor properties [135].

Inducible systems to regulate gene expression and/or turn on signaling pathways are an attractive approach to control activation and function of immune cells. Proof-of-concept studies have shown that inducible systems can also be utilized to control the expression and function of CAR T cells (Fig. 4) [129, 136]. Other approaches include controlling CAR expression or co-stimulation with a small molecule [137-139]. This control of CAR T cell function could potentially allow the clinician to infuse a relatively small amount gens; (ii) the antigen recognition and signaling domains are encoded by two molecules that also contain a heterodimerizer domain under the control of a small dimerizer molecule; (iii) CAR expression can be linked to the presence of a second antigen; and (iv) CAR expression can be induced by a small molecule

of transgenic $\mathrm{T}$ cells and induce appropriate responses with the injection of a titratable drug. In such approaches, CAR expression and/or activation is only present if two molecular interactions occur, thereby making it more difficult for CAR $\mathrm{T}$ cells to initiate signaling, yet 'safer' against off-target effects towards normal tissue. For example, infused T cells, including CAR T cells, initially accumulate in the lung, before they migrate to tumor sites. Inducing CAR expression or co-stimulation once the bulk of CAR T cells have left the lung should limit potential toxicities to normal lung tissues.

\subsection{Suicide Genes}

If adverse events should arise, several approaches have been developed to completely turn off or ablate CAR T cells in vivo [140]. The first approach relies on the expression of an enzyme that activates a prodrug into a toxic compound. Clinical studies with $\mathrm{T}$ cells transduced with the herpes simplex virus thymidine kinase (HSV-tk) gene have shown that administration of the prodrug, ganciclovir, efficiently ablates HSV-tk-transduced T cells in vivo [141]. The second approach consists of genes that take advantage of dimerizing molecules and that can be specifically activated to induce $\mathrm{T}$ cell apoptosis. T cells that express an inducible caspase 9 gene $(i C 9)$ can be effectively ablated in preclinical models and in patients by administration of a small-molecule drug (chemical inducer of dimerization [CID], AP1903) [142, 143]. Additionally, repeated doses of CID were able to eliminate a residual percentage of repopulating cells that express low levels of $i C 9$ [144], indicating that repeated 
doses of CID to activate inducible genes are safe and functional. Other dimerizer systems take advantage of Fas [145] or other molecules in the apoptosis or necroptosis pathways, as reviewed elsewhere [146]. Lastly, expression of a cell surface antigen on engineered T cells such as truncated CD20 or EGFR allows the elimination of T cells with FDA-approved mAbs that induce complement activation and/or antibodydependent cellular cytotoxicity (ADCC) [147, 148]. Currently, several clinical trials are testing such an approach with CD19-CAR and CD123-CAR T cells using truncated EGFR (NCT02028455, NCT02706405, NCT01865617, NCT02146924, NCT02159495).

\section{Conclusion}

Although CAR T cells have shown impressive clinical benefit with lasting effects in CD19+ hematological malignancies, clinical application of CAR T cells for the treatment of solid tumors is still in its beginning phases, with only a handful of complete responses achieved. Hindered by the heterogeneity and complexity of the solid tumor microenvironment, current CAR T cells by themselves may not completely be able to eliminate established tumors. However, recent advances in understanding how CAR T cells function highlight that these cells can be further modified or combined with other treatment modalities to enhance their antitumor activity. Thus, we remain cautiously optimistic that additional genetic modifications of CAR T cells will enhance their activity against solid tumors in humans. Indeed, several genetic approaches that improve CAR T cell expansion, persistence, homing to tumor sites, and their ability to function in the hostile tumor microenvironment are in early phase clinical testing or set to be evaluated in clinical studies within the next 5 years.

\section{Compliance with Ethical Standards}

Funding The authors were supported by US National Institutes of Health (NIH) 1R01CA173750 and 1R01NS106379-01A1, and Cancer Prevention and Research Institute of Texas (CPRIT) grant RP101335.

Conflict of Interest Melinda Mata has no conflict of interest; she is currently an employee of Immatics US, Inc. Stephen Gottschalk has patents and patent applications in the field of T cell therapy and gene therapy for cancer, is a consultant of ViraCyte, LLC, a member of the data safety monitoring board of Immatics US, Inc., and received research funding from Tessa Therapeutics LTD.

\section{References}

1. Sadelain M. Chimeric antigen receptors: driving immunology towards synthetic biology. Curr Opin Immunol. 2016;41:68-76. https://doi.org/10.1016/j.coi.2016.06.004.
2. Maus MV, June $\mathrm{CH}$. Making better chimeric antigen receptors for adoptive T-cell therapy. Clin Cancer Res. 2016;22(8):187584. https://doi.org/10.1158/1078-0432.CCR-15-1433.

3. Jensen MC, Riddell SR. Designing chimeric antigen receptors to effectively and safely target tumors. Curr Opin Immunol. 2015;33:9-15. https://doi.org/10.1016/j.coi.2015.01.002.

4. Dotti G, Gottschalk S, Savoldo B, Brenner MK. Design and development of therapies using chimeric antigen receptorexpressing T cells. Immunol Rev. 2014;257(1):107-26. https ://doi.org/10.1111/imr.12131.

5. Porter DL, Levine BL, Kalos M, Bagg A, June CH. Chimeric antigen receptor-modified $\mathrm{T}$ cells in chronic lymphoid leukemia. N Engl J Med. 2011;365(8):725-33. https://doi. org/10.1056/NEJMoa1103849.

6. Grupp SA, Kalos M, Barrett D, Aplenc R, Porter DL, Rheingold SR, et al. Chimeric antigen receptor-modified $\mathrm{T}$ cells for acute lymphoid leukemia. N Engl J Med. 2013;368(16):150918. https://doi.org/10.1056/NEJMoa1215134.

7. Maude SL, Frey N, Shaw PA, Aplenc R, Barrett DM, Bunin $\mathrm{NJ}$, et al. Chimeric antigen receptor $\mathrm{T}$ cells for sustained remissions in leukemia. N Engl J Med. 2014;371(16):1507-17. https ://doi.org/10.1056/NEJMoa1407222.

8. Porter DL, Hwang WT, Frey NV, Lacey SF, Shaw PA, Loren $\mathrm{AW}$, et al. Chimeric antigen receptor $\mathrm{T}$ cells persist and induce sustained remissions in relapsed refractory chronic lymphocytic leukemia. Sci Transl Med. 2015;7(303):303ra139. https ://doi.org/10.1126/scitranslmed.aac5415.

9. Maude SL, Laetsch TW, Buechner J, Rives S, Boyer M, Bittencourt $\mathrm{H}$, et al. Tisagenlecleucel in children and young adults with B-cell lymphoblastic leukemia. N Engl J Med. 2018;378(5):439-48. https://doi.org/10.1056/NEJMoa1709 866.

10. Park JH, Riviere I, Gonen M, Wang X, Senechal B, Curran $\mathrm{KJ}$, et al. Long-term follow-up of CD19 CAR therapy in acute lymphoblastic leukemia. N Engl J Med. 2018;378(5):449-59. https://doi.org/10.1056/NEJMoa1709919.

11. Gardner RA, Finney O, Annesley C, Brakke H, Summers C, Leger K, et al. Intent-to-treat leukemia remission by CD19 CAR $\mathrm{T}$ cells of defined formulation and dose in children and young adults. Blood. 2017;129(25):3322-31. https://doi.org/10.1182/ blood-2017-02-769208.

12. Susanibar Adaniya SP, Cohen AD, Garfall AL. CAR T cell immunotherapy for Multiple Myeloma A review of current data and potential clinical applications. Am J Hematol. 2019. https:// doi.org/10.1002/ajh.25428 (Epub 2019 Feb 7).

13. Gross G, Waks T, Eshhar Z. Expression of immunoglobulin-T-cell receptor chimeric molecules as functional receptors with antibody-type specificity. Proc Natl Acad Sci USA. 1989;86(24):10024-8.

14. Eshhar Z, Waks T, Gross G, Schindler DG. Specific activation and targeting of cytotoxic lymphocytes through chimeric single chains consisting of antibody-binding domains and the gamma or zeta subunits of the immunoglobulin and T-cell receptors. Proc Natl Acad Sci USA. 1993;90(2):720-4.

15. Kahlon KS, Brown C, Cooper LJ, Raubitschek A, Forman SJ, Jensen MC. Specific recognition and killing of glioblastoma multiforme by interleukin 13-zetakine redirected cytolytic $\mathrm{T}$ cells. Cancer Res. 2004;64(24):9160-6.

16. Pameijer CR, Navanjo A, Meechoovet B, Wagner JR, Aguilar $\mathrm{B}$, Wright $\mathrm{CL}$, et al. Conversion of a tumor-binding peptide identified by phage display to a functional chimeric $\mathrm{T}$ cell antigen receptor. Cancer Gene Ther. 2007;14(1):91-7. https://doi. org/10.1038/sj.cgt.7700993.

17. Hudecek M, Sommermeyer D, Kosasih PL, Silva-Benedict A, Liu L, Rader C, et al. The nonsignaling extracellular spacer domain of chimeric antigen receptors is decisive for in vivo 
antitumor activity. Cancer Immunol Res. 2015;3(2):125-35. https://doi.org/10.1158/2326-6066.CIR-14-0127.

18. Kershaw MH, Westwood JA, Parker LL, Wang G, Eshhar Z, Mavroukakis SA, et al. A phase I study on adoptive immunotherapy using gene-modified $\mathrm{T}$ cells for ovarian cancer. Clin Cancer Res. 2006;12(20 Pt 1):6106-15.

19. Park JR, Digiusto DL, Slovak M, Wright C, Naranjo A, Wagner J, et al. Adoptive transfer of chimeric antigen receptor redirected cytolytic T lymphocyte clones in patients with neuroblastoma. Mol Ther. 2007;15(4):825-33.

20. Guedan S, Chen X, Madar A, Carpenito C, McGettigan SE, Frigault MJ, et al. ICOS-based chimeric antigen receptors program bipolar TH17/TH1 cells. Blood. 2014;124(7):1070-80. https://doi.org/10.1182/blood-2013-10-535245.

21. Guedan S, Posey Jr AD, Shaw C, Wing A, Da T, Patel PR, et al. Enhancing CAR T cell persistence through ICOS and 4-1BB costimulation. JCI Insight. Epub 2018 Jan 11. https:// doi.org/10.1172/jci.insight.96976.

22. Savoldo B, Ramos CA, Liu E, Mims MP, Keating MJ, Carrum $\mathrm{G}$, et al. CD28 costimulation improves expansion and persistence of chimeric antigen receptor-modified $\mathrm{T}$ cells in lymphoma patients. J Clin Invest. 2011;121(5):1822-6. https ://doi.org/10.1172/JCI46110.

23. Long AH, Haso WM, Shern JF, Wanhainen KM, Murgai $\mathrm{M}$, Ingaramo $\mathrm{M}$, et al. 4-1BB costimulation ameliorates $\mathrm{T}$ cell exhaustion induced by tonic signaling of chimeric antigen receptors. Nature Med. 2015;21(6):581-90. https://doi. org/10.1038/nm.3838.

24. Kawalekar OU, O'Connor RS, Fraietta JA, Guo L, McGettigan SE, Posey AD Jr, et al. Distinct signaling of coreceptors regulates specific metabolism pathways and impacts memory development in CAR T cells. Immunity. 2016;44(2):380-90. https://doi.org/10.1016/j.immuni.2016.01.021.

25. Beatty GL, O'Hara MH, Lacey SF, Torigian DA, Nazimuddin F, Chen F, et al. Activity of mesothelin-specific chimeric antigen receptor $\mathrm{T}$ cells against pancreatic carcinoma metastases in a phase 1 trial. Gastroenterology. 2018;155(1):29-32. https ://doi.org/10.1053/j.gastro.2018.03.029.

26. Brown CE, Alizadeh D, Starr R, Weng L, Wagner JR, Naranjo A, et al. Regression of glioblastoma after chimeric antigen receptor T-cell therapy. N Engl J Med. 2016;375(26):2561-9. https://doi.org/10.1056/NEJMoa1610497.

27. O'Rourke DM, Nasrallah MP, Desai A, Melenhorst JJ, Mansfield K, Morrissette JJD, et al. A single dose of peripherally infused EGFRvIII-directed CAR T cells mediates antigen loss and induces adaptive resistance in patients with recurrent glioblastoma. Sci Transl Med. 2017;9(399):eaaa0984. https://doi. org/10.1126/scitranslmed.aaa0984.

28. Heczey A, Louis CU, Savoldo B, Dakhova O, Durett A, Grilley $\mathrm{B}$, et al. CAR $\mathrm{T}$ cells administered in combination with lymphodepletion and PD-1 inhibition to patients with neuroblastoma. Mol Ther. 2017;25(9):2214-24. https://doi. org/10.1016/j.ymthe.2017.05.012.

29. Stephan MT, Ponomarev V, Brentjens RJ, Chang AH, Dobrenkov KV, Heller G, et al. T cell-encoded CD80 and 4-1BBL induce auto- and transcostimulation, resulting in potent tumor rejection. Nat Med. 2007;13(12):1440-9.

30. Zhao Z, Condomines M, van der Stegen SJC, Perna F, Kloss $\mathrm{CC}$, Gunset G, et al. Structural design of engineered costimulation determines tumor rejection kinetics and persistence of CAR T cells. Cancer Cell. 2015;28(4):415-28. https://doi. org/10.1016/j.ccell.2015.09.004.

31. Milone MC, Bhoj VG. The pharmacology of T cell therapies. Mol Ther Methods Clin Dev. 2018;8:210-21. https://doi. org/10.1016/j.omtm.2018.01.010.
32. Fraietta JA, Lacey SF, Orlando EJ, Pruteanu-Malinici I, Gohil $\mathrm{M}$, Lundh S, et al. Determinants of response and resistance to CD19 chimeric antigen receptor (CAR) T cell therapy of chronic lymphocytic leukemia. Nat Med. 2018;24(5):563-71. https://doi. org/10.1038/s41591-018-0010-1.

33. Mueller KT, Waldron E, Grupp SA, Levine JE, Laetsch TW, Pulsipher MA, et al. Clinical pharmacology of tisagenlecleucel in B-cell acute lymphoblastic leukemia. Clin Cancer Res. 2018;24(24):6175-84. https://doi.org/10.1158/1078-0432. CCR-18-0758.

34. Scholler J, Brady TL, Binder-Scholl G, Hwang WT, Plesa G, Hege KM, et al. Decade-long safety and function of retroviralmodified chimeric antigen receptor T cells. Sci Transl Med. 2012;4(132):132ra53. https://doi.org/10.1126/scitranslm ed.3003761.

35. Hay KA, Hanafi LA, Li D, Gust J, Liles WC, Wurfel MM, et al. Kinetics and biomarkers of severe cytokine release syndrome after CD19 chimeric antigen receptor-modified T-cell therapy. Blood. 2017;130(21):2295-306. https://doi.org/10.1182/blood -2017-06-793141.

36. Berger C, Jensen MC, Lansdorp PM, Gough M, Elliott C, Riddell SR. Adoptive transfer of effector CD8+ T cells derived from central memory cells establishes persistent $\mathrm{T}$ cell memory in primates. J Clin Invest. 2008;118(1):294-305.

37. Klebanoff CA, Khong HT, Antony PA, Palmer DC, Restifo NP. Sinks, suppressors and antigen presenters: how lymphodepletion enhances T cell-mediated tumor immunotherapy. Trends Immunol. 2005;26(2):111-7.

38. Gattinoni L, Lugli E, Ji Y, Pos Z, Paulos CM, Quigley MF, et al. A human memory $\mathrm{T}$ cell subset with stem cell-like properties. Nat Med. 2011;17(10):1290-7. https://doi.org/10.1038/nm.2446.

39. Gattinoni L, Finkelstein SE, Klebanoff CA, Antony PA, Palmer DC, Spiess PJ, et al. Removal of homeostatic cytokine sinks by lymphodepletion enhances the efficacy of adoptively transferred tumor-specific CD8+ T cells. J Exp Med. 2005;202(7):907-12.

40. Sommermeyer D, Hudecek M, Kosasih PL, Gogishvili T, Maloney DG, Turtle CJ, et al. Chimeric antigen receptor-modified $\mathrm{T}$ cells derived from defined CD8+ and CD4+ subsets confer superior antitumor reactivity in vivo. Leukemia. 2016;30(2):492500. https://doi.org/10.1038/leu.2015.247.

41. Turtle CJ, Hanafi LA, Berger C, Hudecek M, Pender B, Robinson E, et al. Immunotherapy of non-Hodgkin's lymphoma with a defined ratio of CD8+ and CD4+ CD19-specific chimeric antigen receptor-modified T cells. Sci Transl Med. 2016;8(355):355ra116. https://doi.org/10.1126/scitranslm ed.aaf8621.

42. Wang D, Aguilar B, Starr R, Alizadeh D, Brito A, Sarkissian A, et al. Glioblastoma-targeted CD4+ CAR T cells mediate superior antitumor activity. JCI Insight. Epub 2018 May 17. https://doi. org/10.1172/jci.insight.99048.

43. Omer B, Castillo PA, Tashiro H, Shum T, Huynh MTA, Cardenas $\mathrm{M}$, et al. Chimeric antigen receptor signaling domains differentially regulate proliferation and native $\mathrm{T}$ cell receptor function in virus-specific T cells. Front Med (Lausanne). 2018;5:343. https ://doi.org/10.3389/fmed.2018.00343.

44. Pule MA, Savoldo B, Myers GD, Rossig C, Russell HV, Dotti $\mathrm{G}$, et al. Virus-specific $\mathrm{T}$ cells engineered to coexpress tumorspecific receptors: persistence and antitumor activity in individuals with neuroblastoma. Nat Med. 2008;14(11):1264-70.

45. Louis CU, Savoldo B, Dotti G, Pule M, Yvon E, Myers GD, et al. Antitumor activity and long-term fate of chimeric antigen receptor-positive T cells in patients with neuroblastoma. Blood. 2011;118(23):6050-6. https://doi.org/10.1182/blood-2011-05354449 .

46. Ahmed N, Brawley V, Hegde M, Bielamowicz K, Kalra M, Landi $\mathrm{D}$, et al. HER2-specific chimeric antigen receptor-modified 
virus-specific $\mathrm{T}$ cells for progressive glioblastoma: a phase 1 dose-escalation trial. JAMA Oncol. 2017;3(8):1094-101. https ://doi.org/10.1001/jamaoncol.2017.0184.

47. Ghoneim HE, Fan Y, Moustaki A, Abdelsamed HA, Dash P, Dogra P, et al. De novo epigenetic programs inhibit PD-1 blockade-mediated T cell rejuvenation. Cell. 2017;170(1):142-57.e19. https://doi.org/10.1016/j.cell.2017.06.007.

48. Abdelsamed HA, Zebley CC, Youngblood B. Epigenetic maintenance of acquired gene expression programs during memory CD8 T cell homeostasis. Front Immunol. 2018;9:6. https://doi. org/10.3389/fimmu.2018.00006.

49. Fraietta JA, Nobles CL, Sammons MA, Lundh S, Carty SA, Reich TJ, et al. Disruption of TET2 promotes the therapeutic efficacy of CD19-targeted T cells. Nature. 2018;558(7709):307-12. https://doi.org/10.1038/s41586-018-0178-z.

50. Xu Y, Zhang M, Ramos CA, Durett A, Liu E, Dakhova O, et al. Closely related T-memory stem cells correlate with in vivo expansion of CAR.CD19-T cells and are preserved by IL-7 and IL-15. Blood. 2014;123(24):3750-9. https://doi.org/10.1182/ blood-2014-01-55217.

51. Cieri N, Camisa B, Cocchiarella F, Forcato M, Oliveira G, Provasi E, et al. IL-7 and IL-15 instruct the generation of human memory stem $\mathrm{T}$ cells from naive precursors. Blood. 2013;121(4):573-84. https://doi.org/10.1182/blood-2012-05431718.

52. Hinrichs CS, Spolski R, Paulos CM, Gattinoni L, Kerstann KW, Palmer DC, et al. IL-2 and IL-21 confer opposing differentiation programs to CD8+ T cells for adoptive immunotherapy. Blood. 2008;111(11):5326-33. https://doi.org/10.1182/blood-2007-09113050.

53. Li Y, Bleakley M, Yee C. IL-21 influences the frequency, phenotype, and affinity of the antigen-specific CD8 T cell response. J Immunol. 2005;175(4):2261-9.

54. Gattinoni L, Klebanoff CA, Restifo NP. Pharmacologic induction of CD8+ T cell memory: better living through chemistry. Sci Transl Med. 2009;1(11):11ps2. https://doi.org/10.1126/scitr anslmed.3000302.

55. Muralidharan S, Hanley PJ, Liu E, Chakraborty R, Bollard C, Shpall E, et al. Activation of Wnt signaling arrests effector differentiation in human peripheral and cord blood-derived $\mathrm{T}$ lymphocytes. J Immunol. 2011;187(10):5221-32. https://doi. org/10.4049/jimmunol.1101585.

56. Rao RR, Li Q, Odunsi K, Shrikant PA. The mTOR kinase determines effector versus memory $\mathrm{CD} 8+\mathrm{T}$ cell fate by regulating the expression of transcription factors T-bet and Eomesodermin. Immunity. 2010;32(1):67-78. https://doi.org/10.1016/j.immun i. 2009 .

57. Macintyre AN, Finlay D, Preston G, Sinclair LV, Waugh CM, Tamas $\mathrm{P}$, et al. Protein kinase B controls transcriptional programs that direct cytotoxic $\mathrm{T}$ cell fate but is dispensable for $\mathrm{T}$ cell metabolism. Immunity. 2011;34(2):224-36. https://doi. org/10.1016/j.immuni.2011.01.012.

58. Das RK, Vernau L, Grupp SA, Barrett DM. Naive T cell deficits at diagnosis and after chemotherapy impair cell therapy potential in pediatric cancers. Cancer Discov. Epub 2019 Jan 10. https:// doi.org/10.1158/2159-8290.CD-18-1314.

59. Dudley ME, Wunderlich JR, Robbins PF, Yang JC, Hwu P, Schwartzentruber DJ, et al. Cancer regression and autoimmunity in patients after clonal repopulation with antitumor lymphocytes. Science. 2002;298(5594):850-4.

60. Louis CU, Straathof K, Bollard CM, Gerken C, Huls MH, Gresik $\mathrm{MV}$, et al. Enhancing the in vivo expansion of adoptively transferred EBV-specific CTL with lymphodepleting CD45 monoclonal antibodies in NPC patients. Blood. 2009;113(11):2442-50.

61. Agarwal A, Shen LY, Kirk AD. The role of alemtuzumab in facilitating maintenance immunosuppression minimization following solid organ transplantation. Transpl Immunol. 2008;20(1-2):611. https://doi.org/10.1016/j.trim.2008.09.003.

62. Qasim W, Zhan H, Samarasinghe S, Adams S, Amrolia P, Stafford S, et al. Molecular remission of infant B-ALL after infusion of universal TALEN gene-edited CAR T cells. Sci Transl Med. 2017. https://doi.org/10.1126/scitranslmed.aaj2013.

63. Rosenberg SA. IL-2: the first effective immunotherapy for human cancer. J Immunol. 2014;192(12):5451-8. https://doi. org/10.4049/jimmunol.1490019.

64. Conlon KC, Lugli E, Welles HC, Rosenberg SA, Fojo AT, Morris JC, et al. Redistribution, hyperproliferation, activation of natural killer cells and CD8 T cells, and cytokine production during firstin-human clinical trial of recombinant human interleukin-15 in patients with cancer. J Clin Oncol. 2015;33(1):74-82. https://doi. org/10.1200/JCO.2014.57.3329.

65. Lacy MQ, Jacobus S, Blood EA, Kay NE, Rajkumar SV, Greipp PR. Phase II study of interleukin-12 for treatment of plateau phase multiple myeloma (E1A96): a trial of the Eastern Cooperative Oncology Group. Leuk Res. 2009;33(11):1485-9. https ://doi.org/10.1016/j.leukres.2009.01.020.

66. Cohen J. IL-12 deaths: explanation and a puzzle. Science. 1995;270(5238):908.

67. Mueller K, Schweier O, Pircher H. Efficacy of IL-2- versus IL15-stimulated CD8 T cells in adoptive immunotherapy. Eur J Immunol. 2008;38(10):2874-85.

68. Hoyos V, Savoldo B, Quintarelli C, Mahendravada A, Zhang $\mathrm{M}$, Vera $\mathrm{J}$, et al. Engineering CD19-specific T lymphocytes with interleukin-15 and a suicide gene to enhance their anti-lymphoma/leukemia effects and safety. Leukemia. 2010;24(6):1160-70.

69. Krenciute G, Prinzing BL, Yi Z, Wu MF, Liu H, Dotti G, et al. Transgenic expression of IL15 improves antiglioma activity of IL13Ralpha2-CAR T cells but results in antigen loss variants. Cancer Immunol Res. 2017;5(7):571-81. https://doi. org/10.1158/2326-6066.CIR-16-0376.

70. Chen Y, Sun C, Landoni E, Metelitsa LS, Dotti G, Savoldo B. Eradication of neuroblastoma by $\mathrm{T}$ cells redirected with an optimized GD2-specific chimeric antigen receptor and interleukin-15. Clin Cancer Res. 2019. https://doi.org/10.1158/10780432.CCR-18-1811 (Epub 2019 Jan 7).

71. Chmielewski M, Kopecky C, Hombach AA, Abken H. IL-12 release by engineered $\mathrm{T}$ cells expressing chimeric antigen receptors can effectively muster an antigen-independent macrophage response on tumor cells that have shut down tumor antigen expression. Cancer Res. 2011;71(17):5697-706. https://doi. org/10.1158/0008-5472.CAN-11-0103.

72. Chinnasamy D, Yu Z, Kerkar SP, Zhang L, Morgan RA, Restifo NP, et al. Local delivery of interleukin-12 using T cells targeting VEGF receptor-2 eradicates multiple vascularized tumors in mice. Clin Cancer Res. 2012;18(6):1672-83. https://doi. org/10.1158/1078-0432.CCR-11-3050.

73. Zhang L, Morgan RA, Beane JD, Zheng Z, Dudley ME, Kas$\operatorname{sim} \mathrm{SH}$, et al. Tumor-infiltrating lymphocytes genetically engineered with an inducible gene encoding interleukin-12 for the immunotherapy of metastatic melanoma. Clin Cancer Res. 2015;21(10):2278-88. https://doi.org/10.1158/1078-0432. CCR-14-2085.

74. Koneru M, Purdon TJ, Spriggs D, Koneru S, Brentjens RJ. IL-12 secreting tumor-targeted chimeric antigen receptor $\mathrm{T}$ cells eradicate ovarian tumors in vivo. Oncoimmunology. 2015;4(3):e994446. https://doi.org/10.4161/21624 02X.2014.994446.

75. Hu B, Ren J, Luo Y, Keith B, Young RM, Scholler J, et al. Augmentation of antitumor immunity by human and mouse CAR T cells secreting IL-18. Cell Rep. 2017;20(13):3025-33. https:// doi.org/10.1016/j.celrep.2017.09.002. 
76. Avanzi MP, Yeku O, Li X, Wijewarnasuriya DP, van Leeuwen DG, Cheung K, et al. Engineered tumor-targeted T cells mediate enhanced anti-tumor efficacy both directly and through activation of the endogenous immune system. Cell Rep. 2018;23(7):213041. https://doi.org/10.1016/j.celrep.2018.04.051.

77. Chmielewski M, Abken H. CAR T cells releasing IL-18 convert to T-Bet(high) FoxO1(low) effectors that exhibit augmented activity against advanced solid tumors. Cell Rep. 2017;21(11):3205-19. https://doi.org/10.1016/j.celrep.2017.11.063.

78. Vera JF, Hoyos V, Savoldo B, Quintarelli C, Giordano Attianese GM, Leen AM, et al. Genetic manipulation of tumor-specific cytotoxic T lymphocytes to restore responsiveness to IL-7. Mol Ther. 2009;17(5):880-8.

79. Perna SK, Pagliara D, Mahendravada A, Liu H, Brenner MK, Savoldo B, et al. Interleukin-7 mediates selective expansion of tumor-redirected cytotoxic T lymphocytes (CTLs) without enhancement of regulatory T-cell inhibition. Clin Cancer Res. 2014;20(1):131-9. https://doi.org/10.1158/1078-0432. CCR-13-1016.

80. Shum T, Omer B, Tashiro H, Kruse RL, Wagner DL, Parikh $\mathrm{K}$, et al. Constitutive signaling from an engineered IL7 receptor promotes durable tumor elimination by tumor-redirected T cells. Cancer Discov. 2017;7(11):1238-47. https://doi. org/10.1158/2159-8290.CD-17-0538.

81. Markley JC, Sadelain M. IL-7 and IL-21 are superior to IL-2 and IL-15 in promoting human T cell-mediated rejection of systemic lymphoma in immunodeficient mice. Blood. 2010;115(17):350819. https://doi.org/10.1182/blood-2009-09-241398.

82. Ritchie DS, Neeson PJ, Khot A, Peinert S, Tai T, Tainton K, et al. Persistence and efficacy of second generation CAR T cell against the LeY antigen in acute myeloid leukemia. Mol Ther. 2013;21(11):2122-9. https://doi.org/10.1038/mt.2013.154.

83. Sarvaiya PJ, Guo D, Ulasov I, Gabikian P, Lesniak MS. Chemokines in tumor progression and metastasis. Oncotarget. 2013;4(12):2171-85. https://doi.org/10.18632/oncotarget.1426.

84. Craddock JA, Lu A, Bear A, Pule M, Brenner MK, Rooney CM, et al. Enhanced tumor trafficking of GD2 chimeric antigen receptor T cells by expression of the chemokine receptor CCR2b. J Immunother. 2010;33(8):780-8. https://doi.org/10.1097/ cji.0b013e3181ee6675.

85. Moon EK, Carpenito C, Sun J, Wang LC, Kapoor V, Predina J, et al. Expression of a functional CCR2 receptor enhances tumor localization and tumor eradication by retargeted human $\mathrm{T}$ cells expressing a mesothelin-specific chimeric antibody receptor. Clin Cancer Res. 2011;17(14):4719-30. https://doi.org/10.1158/10780432.CCR-11-0351.

86. Di Stasi A, De Angelis B, Rooney CM, Zhang L, Mahendravada A, Foster AE, et al. T lymphocytes coexpressing CCR4 and a chimeric antigen receptor targeting CD30 have improved homing and antitumor activity in a Hodgkin tumor model. Blood. 2009;113(25):6392-402.

87. Newick K, O'Brien S, Moon E, Albelda SM. CAR T cell therapy for solid tumors. Annu Rev Med. 2017;68:139-52. https://doi. org/10.1146/annurev-med-062315-120245.

88. Nishio N, Diaconu I, Liu H, Cerullo V, Caruana I, Hoyos V, et al. Armed oncolytic virus enhances immune functions of chimeric antigen receptor-modified $\mathrm{T}$ cells in solid tumors. Cancer Res. 2014;74(18):5195-205. https://doi.org/10.1158/0008-5472. CAN-14-0697.

89. Adusumilli PS, Cherkassky L, Villena-Vargas J, Colovos C, Servais E, Plotkin J, et al. Regional delivery of mesothelin-targeted CAR T cell therapy generates potent and longlasting CD4-dependent tumor immunity. Sci Transl Med. 2014;6(261):261ra151. https://doi.org/10.1126/scitranslm ed.3010162.
90. Sotillo E, Barrett DM, Black KL, Bagashev A, Oldridge D, $\mathrm{Wu} \mathrm{G}$, et al. Convergence of acquired mutations and alternative splicing of CD19 enables resistance to CART-19 immunotherapy. Cancer Discov. 2015;5(12):1282-95. https://doi. org/10.1158/2159-8290.CD-15-1020.

91. Fry TJ, Shah NN, Orentas RJ, Stetler-Stevenson M, Yuan $\mathrm{CM}$, Ramakrishna S, et al. CD22-targeted CAR T cells induce remission in B-ALL that is naive or resistant to CD19-targeted CAR immunotherapy. Nat Med. 2018;24(1):20-8. https://doi. org/10.1038/nm.4441.

92. Zah E, Lin MY, Silva-Benedict A, Jensen MC, Chen YY. T cells expressing CD19/CD20 bispecific chimeric antigen receptors prevent antigen escape by malignant B cells. Cancer Immunol Res. 2016;4(6):498-508. https://doi.org/10.1158/2326-6066. CIR-15-0231.

93. Ruella M, Barrett DM, Kenderian SS, Shestova O, Hofmann TJ, Perazzelli J, et al. Dual CD19 and CD123 targeting prevents antigen-loss relapses after CD19-directed immunotherapies. J Clin Invest. 2016;126(10):3814-26. https://doi.org/10.1172/ JCI87366.

94. Qin H, Ramakrishna S, Nguyen S, Fountaine TJ, Ponduri A, Stetler-Stevenson M, et al. Preclinical development of bivalent chimeric antigen receptors targeting both CD19 and CD22. Mol Ther Oncolytics. 2018;11:127-37. https://doi.org/10.1016/j. omto.2018.10.006.

95. Hegde M, Mukherjee M, Grada Z, Pignata A, Landi D, Navai SA, et al. Tandem CAR T cells targeting HER2 and IL13Ralpha2 mitigate tumor antigen escape. J Clin Invest. 2016;126(8):303652. https://doi.org/10.1172/JCI83416.

96. Bielamowicz K, Fousek K, Byrd TT, Samaha H, Mukherjee M, Aware N, et al. Trivalent CAR T-cells overcome interpatient antigenic variability in glioblastoma. Neuro Oncol. 2018;20(4):50618. https://doi.org/10.1093/neuonc/nox182.

97. Wing A, Fajardo CA, Posey AD Jr, Shaw C, Da T, Young $\mathrm{RM}$, et al. Improving CART-cell therapy of solid tumors with oncolytic virus-driven production of a bispecific T-cell engager. Cancer Immunol Res. 2018;6(5):605-16. https://doi. org/10.1158/2326-6066.CIR-17-0314.

98. Moon YW, Hajjar J, Hwu P, Naing A. Targeting the indoleamine 2,3-dioxygenase pathway in cancer. J Immunother Cancer. 2015;3:51. https://doi.org/10.1186/s40425-015-0094-9.

99. Mussai F, Egan S, Hunter S, Webber H, Fisher J, Wheat R, et al. Neuroblastoma arginase activity creates an immunosuppressive microenvironment that impairs autologous and engineered immunity. Cancer Res. 2015;75(15):3043-53. https://doi. org/10.1158/0008-5472.CAN-14-3443.

100. Leone RD, Emens LA. Targeting adenosine for cancer immunotherapy. J Immunother Cancer. 2018;6(1):57. https://doi. org/10.1186/s40425-018-0360-8.

101. Young A, Mittal D, Stagg J, Smyth MJ. Targeting cancerderived adenosine: new therapeutic approaches. Cancer Discov. 2014;4(8):879-88. https://doi.org/10.1158/2159-8290. CD-14-0341.

102. Gaggianesi M, Turdo A, Chinnici A, Lipari E, Apuzzo T, Benfante A, et al. IL4 primes the dynamics of breast cancer progression via DUSP4 inhibition. Cancer Res. 2017;77(12):3268-79. https://doi.org/10.1158/0008-5472.CAN-16-3126.

103. Dennis KL, Blatner NR, Gounari F, Khazaie K. Current status of interleukin-10 and regulatory T-cells in cancer. Curr Opin Oncol. 2013;25(6):637-45. https://doi.org/10.1097/CCO.0000000000 000006.

104. Caruana I, Savoldo B, Hoyos V, Weber G, Liu H, Kim ES, et al. Heparanase promotes tumor infiltration and antitumor activity of CAR-redirected T lymphocytes. Nat Med. 2015;21(5):524-9. https://doi.org/10.1038/nm.3833. 
105. Kakarla S, Chow KK, Mata M, Shaffer DR, Song XT, Wu MF, et al. Antitumor effects of chimeric receptor engineered human $\mathrm{T}$ cells directed to tumor stroma. Mol Ther. 2013;21(8):161120. https://doi.org/10.1038/mt.2013.110.

106. Lo A, Wang LS, Scholler J, Monslow J, Avery D, Newick K, et al. Tumor-promoting desmoplasia is disrupted by depleting FAP-expressing stromal cells. Cancer Res. 2015;75(14):2800 10. https://doi.org/10.1158/0008-5472.CAN-14-3041.

107. Tran E, Chinnasamy D, Yu Z, Morgan RA, Lee CC, Restifo $\mathrm{NP}$, et al. Immune targeting of fibroblast activation protein triggers recognition of multipotent bone marrow stromal cells and cachexia. J Exp Med. 2013;210(6):1125-35. https://doi. org/10.1084/jem.20130110.

108. Zarour HM. Reversing T-cell dysfunction and exhaustion in cancer. Clin Cancer Res. 2016;22(8):1856-64. https://doi. org/10.1158/1078-0432.CCR-15-1849.

109. Moon EK, Wang LC, Dolfi DV, Wilson CB, Ranganathan $\mathrm{R}$, Sun J, et al. Multifactorial T-cell hypofunction that is reversible can limit the efficacy of chimeric antigen receptortransduced human $\mathrm{T}$ cells in solid tumors. Clin Cancer Res. 2014;20(16):4262-73. https://doi.org/10.1158/1078-0432. CCR-13-2627.

110. John LB, Devaud C, Duong CP, Yong CS, Beavis PA, Haynes $\mathrm{NM}$, et al. Anti-PD-1 antibody therapy potently enhances the eradication of established tumors by gene-modified T cells. Clin Cancer Res. 2013;19(20):5636-46. https://doi.org/10.1158/10780432.CCR-13-0458.

111. Thomas DA, Massague J. TGF-beta directly targets cytotoxic $\mathrm{T}$ cell functions during tumor evasion of immune surveillance. Cancer Cell. 2005;8(5):369-80. https://doi.org/10.1016/j. ccr.2005.10.012.

112. Foster AE, Dotti G, Lu A, Khalil M, Brenner MK, Heslop HE, et al. Antitumor activity of EBV-specific T lymphocytes transduced with a dominant negative TGF-beta receptor. J Immunother. 2008;31(5):500-5.

113. Kloss CC, Lee J, Zhang A, Chen F, Melenhorst JJ, Lacey SF, et al. Dominant-negative TGF-beta receptor enhances PSMAtargeted human CAR T cell proliferation and augments prostate cancer eradication. Mol Ther. 2018;26(7):1855-66. https://doi. org/10.1016/j.ymthe.2018.05.003.

114. Bollard CM, Tripic T, Cruz CR, Dotti G, Gottschalk S, Torrano $\mathrm{V}$, et al. Tumor-specific T-cells engineered to overcome tumor immune evasion induce clinical responses in patients with relapsed Hodgkin lymphoma. J Clin Oncol. 2018;36(11):112839. https://doi.org/10.1200/JCO.2017.74.3179.

115. Watanabe N, Anurathapan U, Brenner M, Heslop H, Leen A, Rooney C, et al. Transgenic expression of a novel immunosuppressive signal converter on T cells [abstract no. 398]. Mol Ther. 2013;22(Suppl 1):S153

116. Wilkie S, Burbridge SE, Chiapero-Stanke L, Pereira AC, Cleary $\mathrm{S}$, van der Stegen SJ, et al. Selective expansion of chimeric antigen receptor-targeted T-cells with potent effector function using interleukin-4. J Biol Chem. 2010;285(33):25538-44. https://doi. org/10.1074/jbc.M110.127951.

117. Bajgain P, Tawinwung S, D'Elia L, Sukumaran S, Watanabe N, Hoyos V, et al. CAR T cell therapy for breast cancer: harnessing the tumor milieu to drive $\mathrm{T}$ cell activation. J Immunother Cancer. 2018;6(1):34. https://doi.org/10.1186/s40425-018-0347-5.

118. Rivadeneira DB, Delgoffe GM. Antitumor T-cell reconditioning: improving metabolic fitness for optimal cancer immunotherapy. Clin Cancer Res. 2018;24(11):2473-81. https://doi. org/10.1158/1078-0432.CCR-17-0894.

119. Le Bourgeois T, Strauss L, Aksoylar HI, Daneshmandi S, Seth P, Patsoukis N, et al. Targeting T cell metabolism for improvement of cancer immunotherapy. Front Oncol. 2018;8:237. https://doi. org/10.3389/fonc.2018.00237.
120. Schurich A, Magalhaes I, Mattsson J. Metabolic regulation of CAR T cell function by the hypoxic microenvironment in solid tumors. Immunotherapy. 2019;11(4):335-45. https://doi. org/10.2217/imt-2018-0141.

121. Geiger R, Rieckmann JC, Wolf T, Basso C, Feng Y, Fuhrer T, et al. L-arginine modulates $\mathrm{T}$ cell metabolism and enhances survival and anti-tumor activity. Cell. 2016;167(3):829-42 e13. https ://doi.org/10.1016/j.cell.2016.09.031.

122. Scharping NE, Menk AV, Whetstone RD, Zeng X, Delgoffe GM. Efficacy of PD-1 blockade is potentiated by metformin-induced reduction of tumor hypoxia. Cancer Immunol Res. 2017;5(1):916. https://doi.org/10.1158/2326-6066.CIR-16-0103.

123. Lamers CH, Sleijfer S, Vulto AG, Kruit WH, Kliffen M, Debets R, et al. Treatment of metastatic renal cell carcinoma with autologous T-lymphocytes genetically retargeted against carbonic anhydrase IX: first clinical experience. J Clin Oncol. 2006;24(13):e20-2.

124. Lamers $\mathrm{CH}$, Sleijfer S, van Steenbergen S, van Elzakker P, van Krimpen B, Groot C, et al. Treatment of metastatic renal cell carcinoma with CAIX CAR-engineered T cells: clinical evaluation and management of on-target toxicity. Mol Ther. 2013;21(4):904-12. https://doi.org/10.1038/mt.2013.17.

125. Morgan RA, Yang JC, Kitano M, Dudley ME, Laurencot CM, Rosenberg SA. Case report of a serious adverse event following the administration of $\mathrm{T}$ cells transduced with a chimeric antigen receptor recognizing ERBB2. Mol Ther. 2010;18(4):843-51. https://doi.org/10.1038/mt.2010.24.

126. Ahmed N, Brawley VS, Hegde M, Robertson C, Ghazi A, Gerken $\mathrm{C}$, et al. Human epidermal growth factor receptor 2 (HER2)-specific chimeric antigen receptor-modified $\mathrm{T}$ Cells for the immunotherapy of HER2-positive sarcoma. J Clin Oncol. 2015;33(15):1688-96. https://doi.org/10.1200/ JCO.2014.58.0225.

127. Zhao Y, Moon E, Carpenito C, Paulos CM, Liu X, Brennan AL, et al. Multiple injections of electroporated autologous T cells expressing a chimeric antigen receptor mediate regression of human disseminated tumor. Cancer Res. 2010;70(22):9053-61. https://doi.org/10.1158/0008-5472.CAN-10-2880.

128. Maus MV, Haas AR, Beatty GL, Albelda SM, Levine BL, Liu $\mathrm{X}$, et al. T cells expressing chimeric antigen receptors can cause anaphylaxis in humans. Cancer Immunol Res. 2013;1(1):26-31. https://doi.org/10.1158/2326-6066.CIR-13-0006.

129. Roybal KT, Rupp LJ, Morsut L, Walker WJ, McNally KA, Park JS, et al. Precision tumor recognition by T cells with combinatorial antigen-sensing circuits. Cell. 2016;164(4):770-9. https:// doi.org/10.1016/j.cell.2016.01.011.

130. Liu X, Jiang S, Fang C, Yang S, Olalere D, Pequignot EC, et al. Affinity-tuned ErbB2 or EGFR chimeric antigen receptor $\mathrm{T}$ cells exhibit an increased therapeutic index against tumors in mice. Cancer Res. 2015;75(17):3596-607. https://doi. org/10.1158/0008-5472.CAN-15-0159.

131. Caruso HG, Hurton LV, Najjar A, Rushworth D, Ang S, Olivares $\mathrm{S}$, et al. Tuning sensitivity of CAR to EGFR density limits recognition of normal tissue while maintaining potent antitumor activity. Cancer Res. 2015;75(17):3505-18. https://doi. org/10.1158/0008-5472.CAN-15-0139.

132. Kloss CC, Condomines M, Cartellieri M, Bachmann M, Sadelain $\mathrm{M}$. Combinatorial antigen recognition with balanced signaling promotes selective tumor eradication by engineered T cells. Nat Biotechnol. 2013;31(1):71-5. https://doi.org/10.1038/nbt.2459.

133. Wilkie S, van Schalkwyk MC, Hobbs S, Davies DM, van der Stegen SJ, Pereira AC, et al. Dual targeting of ErbB2 and MUC1 in breast cancer using chimeric antigen receptors engineered to provide complementary signaling. J Clin Immunol. 2012;32(5):1059-70. https://doi.org/10.1007/s1087 5-012-9689-9. 
134. Lanitis E, Poussin M, Klattenhoff AW, Song D, Sandaltzopoulos $\mathrm{R}$, June $\mathrm{CH}$, et al. Chimeric antigen receptor T Cells with dissociated signaling domains exhibit focused antitumor activity with reduced potential for toxicity in vivo. Cancer Immunol Res. 2013;1(1):43-53. https://doi.org/10.1158/2326-6066. CIR-13-0008.

135. Fedorov VD, Themeli M, Sadelain M. PD-1- and CTLA4-based inhibitory chimeric antigen receptors (iCARs) divert off-target immunotherapy responses. Sci Transl Med. 2013;5(215):215ra172. https://doi.org/10.1126/scitranslm ed.3006597.

136. Wu CY, Roybal KT, Puchner EM, Onuffer J, Lim WA. Remote control of therapeutic T cells through a small molecule-gated chimeric receptor. Science. 2015;350(6258):aab4077. https://doi. org/10.1126/science.aab4077.

137. Sakemura R, Terakura S, Watanabe K, Julamanee J, Takagi E, Miyao K, et al. A Tet-on inducible system for controlling CD19-chimeric antigen receptor expression upon drug administration. Cancer Immunol Res. 2016;4(8):658-68. https://doi. org/10.1158/2326-6066.CIR-16-0043.

138. Mata M, Gerken C, Nguyen P, Krenciute G, Spencer DM, Gottschalk S. Inducible activation of MyD88 and CD40 in CAR $\mathrm{T}$ cells results in controllable and potent antitumor activity in preclinical solid tumor models. Cancer Discov. 2017;7(11):1306-19. https://doi.org/10.1158/2159-8290.CD-17-0263.

139. Foster AE, Mahendravada A, Shinners NP, Chang WC, Crisostomo J, Lu A, et al. Regulated expansion and survival of chimeric antigen receptor-modified $\mathrm{T}$ cells using small molecule-dependent inducible MyD88/CD40. Mol Ther. 2017;25(9):2176-88. https://doi.org/10.1016/j.ymthe.2017.06.014.

140. Lupo-Stanghellini MT, Provasi E, Bondanza A, Ciceri F, Bordignon C, Bonini C. Clinical impact of suicide gene therapy in allogeneic hematopoietic stem cell transplantation. Hum Gene Ther. 2010;21(3):241-50. https://doi.org/10.1089/hum.2010.014.

141. Bonini C, Ferrari G, Verzeletti S, Servida P, Zappone E, Ruggieri $\mathrm{L}$, et al. HSV-TK gene transfer into donor lymphocytes for control of allogeneic graft versus leukemia. Science. 1997;276:1719-24.

142. Straathof KC, Pule MA, Yotnda P, Dotti G, Vanin EF, Brenner MK, et al. An inducible caspase 9 safety switch for T-cell therapy. Blood. 2005;105(11):4247-54.

143. Di Stasi A, Tey SK, Dotti G, Fujita Y, Kennedy-Nasser A, Martinez $\mathrm{C}$, et al. Inducible apoptosis as a safety switch for adoptive cell therapy. N Engl J Med. 2011;365(18):1673-83. https://doi. org/10.1056/NEJMoa1106152.

144. Zhou X, Naik S, Dakhova O, Dotti G, Heslop HE, Brenner MK. Serial activation of the inducible caspase 9 safety switch after human stem cell transplantation. Mol Ther. 2016;24(4):823-31. https://doi.org/10.1038/mt.2015.234.

145. Thomis DC, Marktel S, Bonini C, Traversari C, Gilman M, Bordignon $\mathrm{C}$, et al. A Fas-based suicide switch in human $\mathrm{T}$ cells for the treatment of graft-versus-host disease. Blood. 2001;97(5):1249-57.

146. Falcon C, Al-Obaidi M, Di Stasi A. Exploiting cell death pathways for inducible cell elimination to modulate graft-versus-hostdisease. Biomedicines. 2017. https://doi.org/10.3390/biomedicin es5020030.

147. Vogler I, Newrzela S, Hartmann S, Schneider N, Von LD, Koehl $\mathrm{U}$, et al. An improved bicistronic CD20/tCD34 vector for efficient purification and in vivo depletion of gene-modified $\mathrm{T}$ cells for adoptive immunotherapy. Mol Ther. 2010;18(7):1330-8. https:// doi.org/10.1038/mt.2010.83.

148. Wang X, Chang WC, Wong CW, Colcher D, Sherman M, Ostberg $\mathrm{JR}$, et al. A transgene-encoded cell surface polypeptide for selection, in vivo tracking, and ablation of engineered cells. Blood. 2011;118(5):1255-63. https://doi.org/10.1182/blood-2011-02337360.

149. Wang Y, Chen M, Wu Z, Tong C, Dai H, Guo Y, et al. CD133directed CAR $\mathrm{T}$ cells for advanced metastasis malignancies: a phase I trial. Oncoimmunology. 2018;7(7):e1440169. https://doi. org/10.1080/2162402X.2018.1440169.

150. Zhang C, Wang Z, Yang Z, Wang M, Li S, Li Y, et al. Phase I escalating-dose trial of CAR-T therapy targeting CEA(+) metastatic colorectal cancers. Mol Ther. 2017;25(5):1248-58. https ://doi.org/10.1016/j.ymthe.2017.03.010.

151. Thistlethwaite FC, Gilham DE, Guest RD, Rothwell DG, Pillai M, Burt DJ, et al. The clinical efficacy of first-generation carcinoembryonic antigen (CEACAM5)-specific CAR T cells is limited by poor persistence and transient pre-conditioning-dependent respiratory toxicity. Cancer Immunol Immunother. 2017;66(11):1425-36. https://doi.org/10.1007/s0026 2-017-2034-7. 